\title{
Tracing the Emergence of Nordic Allemansrätten through Digitised Parliamentary Sources
}

\section{La Mela, Matti Oula Juhana}

Helsinki University Press

2020-12

La Mela, M O J 2020 , Tracing the Emergence of Nordic Allemansrätten through Digitised Parliamentary Sources . in M Fridlund, M Oiva \& P Paju (eds), Digital histories : Emergent approaches within the new digital history . Helsinki University Press , Helsinki , pp. 181-197 . https://doi.org/10.3313

http://hdl.handle.net/10138/336232

https://doi.org/10.33134/HUP-5-11

cc_by

publishedVersion

Downloaded from Helda, University of Helsinki institutional repository.

This is an electronic reprint of the original article.

This reprint may differ from the original in pagination and typographic detail.

Please cite the original version. 


\title{
Tracing the Emergence of Nordic Allemansrätten through Digitised Parliamentary Sources
}

\author{
Matti La Mela
}

\section{Introduction}

Allemansrätten, a right of public access to nature, is an integral part of the identity and lifestyle of the people in the Nordic countries. This principle, which is commonly seen as an age-old tradition, allows everyone to access and use resources in the wild even without the landowner's consent. Despite its major role in contemporary Nordic societies, the roots and the development of this institution are little researched and not well known. This chapter contributes to the historical revision of allemansrätten by studying public uses of the concept in Finland in the 20th century. Such a broad study is possible using the recently digitised documents of the Finnish Parliament, which offer a unique view on how central societal concepts have been defined and used in public discussion. The chapter asks how and when allemansrätten actually emerged as a term, and to which discursive environments the concept was tied in the public debates of the 20th century.

How to cite this book chapter:

La Mela, M. (2020). Tracing the emergence of Nordic allemansrätten through digitised parliamentary sources. In M. Fridlund, M. Oiva, \& P. Paju (Eds.), Digital histories: Emergent approaches within the new digital history (pp. 181-197). Helsinki: Helsinki University Press. https://doi.org/10.33134/HUP-5-11 
The aim of the chapter is to challenge the common view of allemansrätten as an age-old and stable tradition, and to demonstrate how the concept is historically constructed and has been flexibly used as part of different political discourses. In particular, the chapter focuses on the principle of universality inherent to the modern allemansrätten. Even though it is acknowledged today that allemansrätten took its form only with the modern processes of urbanisation, growth of free time, and development of new ways of recreation in nature after the 1930s, many authors build continuity to pre-modern Nordic legal culture or access practices. ${ }^{1}$ On the other hand, some critics have proposed that allemansrätten was actually an ideological move to socialise private land to the use of everybody. ${ }^{2}$ Most recently, however, a mid-way has been sought, where the past and modern cultures of access to nature are discussed separately, to emphasise differences in the social contexts and to demonstrate the parliamentary political support given to allemansrätten in the 20th century. ${ }^{3}$

The chapter uses methods of text mining, and uses the Finnish parliamentary documents as its source. This digitised data has been created only very recently, and is discussed therefore rather thoroughly in the second section of the chapter. It is notable, however, that other digitised sources, for instance newspapers, have already been used for studying parliamentary debates. ${ }^{4}$ The digitised newspapers are currently available only until 1929. The new digitised parliamentary documents, therefore, are not only an important dataset for studying policy and law-making, but also offer an important perspective over the broader public debate after 1929, which no other complete digital collection in Finland currently represents. The digitised parliamentary sources of other countries have been used in historical and social scientific research. These include straightforward debate analysis through keyword searches, but also the use of more complicated methods such as sentiment analysis. ${ }^{5}$

This chapter studies the history of the uses of allemansrätten in the parliamentary data in two steps. First, in the section entitled 'Allemansrätten Emerges', below, keyword searches and frequency analysis is used for discovering the general trajectory of the term in the complete dataset from 1907 until 2000. The parliamentary debates are understood as reflecting common language use of the time, and thus reflecting topics which were central for the contemporary public discussion. Second, in the section entitled 'Allemansrätten since the 1970s', below, the aim is to study differences in the discursive environments where allemansrätten was used. Key parliamentary debates are identified, and the parliamentary data is text-mined into two detailed debate corpora from the 1970s and 1990s. These two corpora are analysed with collocation analysis and topic modelling, and the results are contrasted with each other. The hypothesis of the chapter is that the term appears only after the Second World War, which has been preliminarily confirmed from sporadic sources. ${ }^{6}$ However, in which discussions did this take place, and how was the modern and commonly acknowledged concept appropriated in the public discussion? 


\section{Digitised Parliamentary Talk of the 20th Century: Quantity and Quality}

Parliamentary documents are a classic source in history. They are used to study the past national legislative work, but also offer a broader view on the political culture and political language, as well as major societal issues of the time. ${ }^{7}$ Internationally, parliamentary sources have been digitised only in the past 10 years and are now available for research use. ${ }^{8}$ In the Finnish case, the parliamentary documents of the latest decades have been available digitally for several years; however, the digitisation of the documents of the unicameral parliament from 1907 until 2000 were finished only recently: the online digital collection was inaugurated in September 2018. ${ }^{9}$

The digital collection includes the documents of the Finnish Eduskunta, unicameral Finnish Parliament, which convened for the first time in 1907, when the country still formed an autonomous Grand Duchy as part of the Russian Empire. The parliamentary reform leading to Eduskunta was radical at its time, as it expanded the suffrage to the whole of the male and female population and, first in the world, enabled women to stand for election. From a more concrete point of view, however, there was important institutional continuity, as the national and local representative rights had already been exercised since the 1860s. The national Diet or Assembly of Estates, which gathered the representatives of the four estates for legislative work, had convened in 1809 and after that regularly since 1863. As Pekonen has shown, foreign parliamentary practices were carefully studied in the 19th century and the basis for the parliamentary procedure was established, for example, regarding minute keeping. ${ }^{10}$

The digitised collection comprises the printed volumes that have been compiled during the parliamentary season (ranging usually from February to January). ${ }^{11}$ The parliamentary sources contain both static documents, which were the basis of the parliamentary work or produced in the legislative process, and dynamic minute keeping, which recorded the speeches and the procedure of the sessions. It is important to note that even though the minutes were recorded in detail and directly, they have gone through minor editing in the transcription process at the Records Office (for example, regarding the use of dialects). ${ }^{12}$

The parliamentary documents follow until 1975 the publication practices established already in the 19th century, according to which the documents were grouped together per legislative case (minutes proceed chronologically). The materials of the season were published both in Finnish and in Swedish, of which the Finnish collection forms the complete collection, and Swedish texts include translations of the main documents and a summary of the minutes. The annual publications consist of two to four volumes of the Minutes of the parliamentary sessions (Pöytäkirjat), one volume of the Swedish summary (Protokoll $i$ sammandrag), three to five volumes of the Documents in each language (Asiakirjat, Handlingar) and the Annexes (Liitteet, only in Finnish). ${ }^{13}$ For 
the season 1975/II (which started in September), the Documents and Annexes began to be regrouped in Documents series (A-F in Finnish, A-D in Swedish) according to their type. Besides this, a separate Index (Hakemisto, Register) was published, which had been included prior to $1975 / \mathrm{II}$ in the last volume of the Minutes. ${ }^{14}$ The index of the Minutes has been extracted during the digitisation into a separate file for the seasons 1948 to 1975/I.

The digitised material has been published online by the Finnish Parliament. ${ }^{15}$ In the digitisation process, the separate volumes have been scanned, opticalcharacter recognised (OCR) and stored as PDF/A files. The online interface allows keyword searching of the text content of the pdf files, which, however, has considerable challenges due to errors and typographical features included in the OCR output. ${ }^{16}$ The separate pdf files (the different printed volumes) can be downloaded and used separately. This complete dataset consists of $92.4 \mathrm{~GB}$ of optically recognised pdfs, of which 61.6 GB are in Finnish and 30.8 GB are in Swedish. The pdf files have been named according to their publication types (described above) and publication year, but the dataset does not include any text or metadata files.

For this chapter, the text content of the pdfs was extracted with the pdftotxt tool included in the open source Xpdf. ${ }^{17}$ The pdf format does not offer a good structure for the text, and the text output was cleaned for the analysis conducted here. In 'Allemansrätten Emerges' below, the raw documents could be used while they suited keyword searches and close reading of the search results. For the topic modelling carried out in 'Allemansrätten since the 1970s', below, two debate corpora were refined manually: only selected law cases were picked, and from these, only speeches by representatives were extracted and corrected into simple text. ${ }^{18}$

As the digitisation of the parliamentary documents has been carried out with printed material, the OCR quality of the material is generally very good. However, it varies a lot and needs cleaning to be used for detailed textual analysis. As there is currently no previous research or evaluation of the quality of the material, I conducted a very rough analysis of the word recognition rates concerning the complete material per decade. I used the LAS-tool, ${ }^{19}$ which has a functionality for word recognition rate..$^{20}$ The recognition was conducted per file, and an average was calculated for document type per year.

As shown in Figure 11.1, the recognition rates are between $60 \%$ and around $95 \%$, mainly being over $80 \%$. In comparison to the digitised Finnish newspapers, the quality is very good, as a word accuracy of around $70 \%$ to $75 \%$ has been reported for the historical newspapers. ${ }^{21}$ It is notable, however, that the quality varies to some degree in the parliamentary material, and is lowest for the documents published in the 1920s and 1930s. Furthermore, the LAS-tool uses only one language when detecting recognition rate in the complete file. The Minutes in particular have a lower detection rate for the earlier years, as Swedish was used more commonly by the MPs. Thus, the real recognition rate is slightly higher than shown in the graph, but the general trend surrounding the quality of the digitisation is clearly visible. 


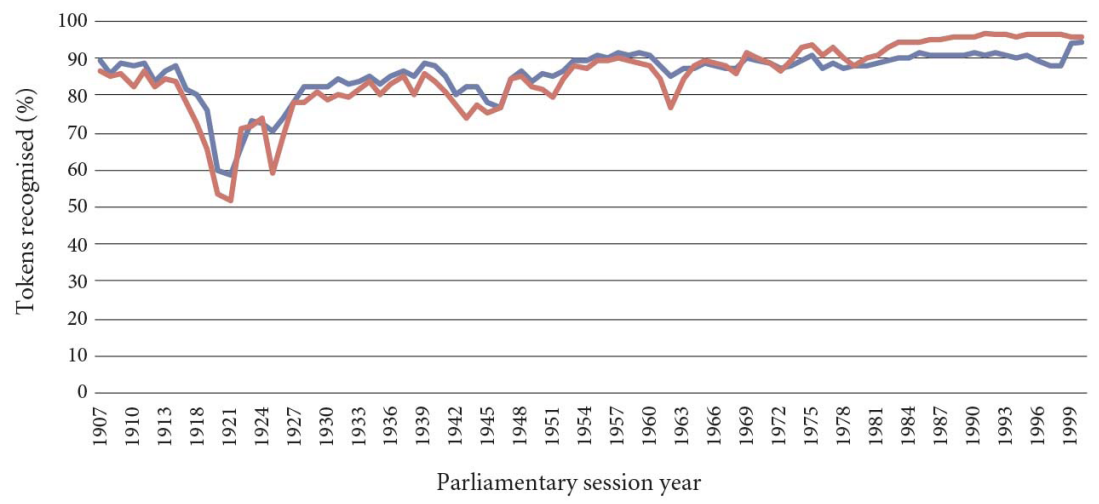

All documents Minutes of the sessions

Figure 11.1: Tokens recognised on average per year in the Finnish-language, digitised parliamentary documents. Source: Author.

\section{Allemansrätten Emerges: From Every Man to Fishing and to Modern Access Rights}

In this section, I will explore the emergence of allemansrätten as a commonly known and shared concept in the Finnish public discussion of the 20th century. This history is not known, and offers an important perspective on the temporal tension inherent in allemansrätten. On the one hand, allemansrätten is commonly narrated as an age-old tradition or as deriving from the specific Nordic culture. For instance, in autumn 2018, the Finnish outdoor association Suomen Latu launched a public campaign broadly visible in the national media, which aims to add allemansrätten to UNESCO's list of intangible cultural heritage. ${ }^{22}$ On the other hand, the scholarship has acknowledged, mainly in the Swedish case, that allemansrätten saw the light of day only after the 1930s, with the development of urbanisation and modern mass outdoor recreation. ${ }^{23}$ As Kardell writes, since its first appearances in the 1930s, allemansrätten 'grew to become part of the Swedish nation's soul (folksjälen)'.24

How is the case with Finland, then? On a general level, it is known that also in Finland, the term allemansrätten, or jokamiehenoikeus in Finnish, becomes commonly used only after the Second World War. ${ }^{25}$ The parliamentary data allows us to study the trajectory of the term during the whole century. It also fills an important gap, as the digitised national newspapers are available only until 1929. I will first trace the appearance of the term in the parliamentary data, and then focus on particular instances by studying, on a sentence level, in which ways allemansrätten could be used in public talk. In this mapping, I will use the complete dataset, and in the following section of the chapter, I will focus on more limited corpora to study the discursive environments in more detail. 


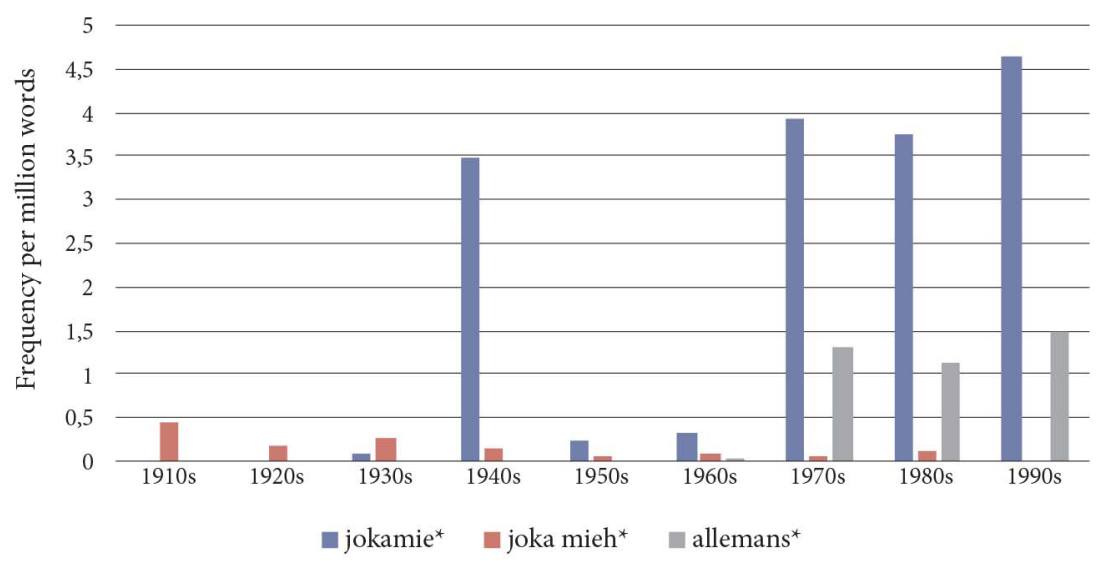

Figure 11.2: Frequencies of 'everyman*' ('jokamie», 'joka mieh* in Finnish, and 'allemans ${ }^{\star}$ in Swedish) per million words in the parliamentary documents per decade. Source: Author.

I used multiple keywords in the search in order to shed light on the differences between the uses in the two national languages, Finnish and Swedish, and to capture a broader variety of terms used. ${ }^{26}$ As we can see from Figure 11.2, there are differences with regard to how much the terms were used. Before the 1940s, the Swedish term allemansrätten is not used at all, and the Finnish 'joka miehen' (every man's) appears to some extent. In the 1940s, there is a curious peak in the use of the term in Finnish. Finally, only in the 1970s, the use of the written forms 'jokamiehen' (everyman's) and 'allemans ${ }^{\star}$ really boom and become common. The other word forms are used less frequently and disappear.

When we look at the actual uses of the terms in the parliamentary data, we can shape three periods. In the pre-Second World War era, the term 'everyman' referred to a common, ordinary person. During the Second World War, 'everyman' was used in the context of nature and outdoor activities with the introduction of the wartime 'everyman's right of fish'. Finally, only gradually since the 1960s, 'everyman' became employed in its main contemporary meaning as describing allemansrätten.

The Finnish 'joka mies', everyman or every man, is obviously a term that has already appeared in the language for a longer amount of time. In this meaning, it refers to an ordinary person or generally everybody. It is important to note that this Finnish term translates into the Swedish 'var man' (everyman), and does not bear similarity to the Swedish-language word root alleman pointing at allmän (common, general) and allmänningar (the commons). In general, then, the origins of the Finnish vocabulary are less bound to land ownership and social conflict. ${ }^{27}$ Moreover, in the early century, the term was not yet used in the context of outdoor activities or access to nature. We find manuals, guidebooks and even magazines for the 'everyman' (for example, the 'Everyman's-and 
every woman's-weekly' first published in 1907, later called the 'Everyman's weekly'). ${ }^{28}$ In the parliamentary data of the early century, this is how ' joka mies' (every man) was used. In the Minutes of 1935, national defence was supported by stating that the 'defence question is a question for every man' ${ }^{29}$

Interestingly, the first major uses of 'everyman' as explicitly concerning public access to nature took place in the early 1940s in relation to fishing rights. During the wartimes, temporary fishing rights were enacted in Finland in 1941 to alleviate the shortage of food. At first, the rights concerned fishing in one's local waters, but these were extended in 1943 to allow for some years fishing for everyone in all parts of the country. The right concerned non-commercial fishing by the household, but allowed special permissions for professional fishers, who were immigrants away from their home lakes. The right became labelled as 'everyman's right to fish' or 'everyman's fishing' (jokamiehen kalastusoikeus, jokamieskalastus or, in Swedish, var mans fiskerätt). ${ }^{30}$ In Parliament, there was also criticism raised against this right; however, its temporary and exceptional nature was acknowledged. In 1946, in the aftermath of the war, it was noted how among the 'everyman fishers' (jokamieskalastaja) ${ }^{31}$ there were also many immigrants and locals who were in dire need of fish. It was noted by the social democrat MP Tuomas Bryggari how this right should not only be made an exception, but 'a general law, so that every citizen would have the right to fish. ${ }^{32}$

The discussion about 'everyman's fishing' continued in the 1950s, but it was only in the 1960s that the 'everyman' was used to refer to the modern allemansrätten. However, we still find discussion about fishing and 'everyman' as everybody or a common person as in 'everyman's sports'. In the parliamentary data, the first uses of allemansrätten is in Finnish in 1964. In his question to the government, the left-wing MP Kalevi Kilpi (and others) asked about how the future outdoor legislation would react to the question of no trespassing signs. Kilpi added how according to 'custom there existed a so-called everyman's right to roam on another's land without the permission of the owner.'33 This is the period when the term allemansrätten became very common in Sweden. The word appeared as part of land planning and urban nature use in the late 1930s, and in the early 1950s, the public in Sweden could read in the newspapers how allemansrätten did not really appear in Swedish law, but gave everyone the right to move freely in the woods since the early times. In Finland, sporadic appearances are found in these years, but the country seemed to follow its western neighbour only in the following decade.

In the 1970s, then, the term allemansrätten became very widely used in the parliamentary data. This peak is explained also by the particular moment, while the new outdoor legislation was discussed in the parliament in the early 1970s. However, this expansion in the use of allemansrätten is also due to the term becoming common in the Finnish language, perhaps even a rhetorical motif describing public access rights in general. The peak in the uses of allemansrätten does not decrease, but stays at the same level and even increases in the following decades. Moreover, the term allemansrätten becomes mainly associated 
with the area of public access rights to nature. Already at the time, the term was commonly used in public and scholarly discussion in Sweden. This is an indication that the interpretation and demarcation of the modern concept of allemansrätten in Finland was influenced by the Swedish discussions, which is also confirmed by the legal scholarly discussion on access rights to public and private spaces in Finland. ${ }^{34}$

Even though the digitised newspaper collections are incomplete, it is important to confirm the results with the newspaper material and use it as a parallel dataset to control possible quality problems related to the parliamentary data. I conducted similar keyword searches in the Finnish National Library newspaper dataset until 1929, and used the Sanoma Digital Archives, which host a handful of major Finnish newspapers with national coverage, such as Helsingin Sanomat and Iltasanomat. The results are very similar. From 1900 until 1929, there are no appearances of allemansrätt $t^{*}$ (or alle mans rätt ${ }^{*}$ ), and I found uses of 'var man' (everyman) similar to the Finnish-language use of 'everybody' and 'common person'. The Sanoma Archives' sources also demonstrate the peak in the 1940s with references to the 'everyman's right to fish'. The first uses of the modern term 'jokamiehenoikeus' (allemansrätten) are found in the 1960s, and the term becomes common in the 1970s material. The first reference from 1962 is in a letter from a reader to the newspaper Helsingin Sanomat about the recent private road legislation and whether walking on private roads was permitted. ${ }^{35}$

It seems clear, then, that the term allemansrätten became commonly used only after the 1960s. How stable have the modern uses been? In the following section, I will explore more carefully the discursive environments where the modern term has been used by contrasting the parliamentary debates of the 1970s with those of the early 1990s - a moment of Finland's economic and political opening, for example, concerning the EC/EU membership.

\section{Allemansrätten since the 1970s: Mapping the Shifts in Discursive Environments}

Today, allemansrätten is a well-known concept which has extended outside its core meaning of public access rights to nature. Allemansrätten has been used in other areas than nature to designate the importance of public access rights-for example, how 'public libraries are an everyman's right'. Moreover, the concept has been branded as something uniting the Nordic countries, but also representing several key values of these societies, such as Nordic freedom, clean nature and equality. ${ }^{36}$ What can we learn about the uses of the concept and its expansion beyond a mere 'right to roam' by looking at the parliamentary debates?

In this section, we investigate and contrast the uses of allemansrätten at two moments in time: in the early 1970s, when allemansrätten was becoming a commonly used concept, and in the early 1990s, when the term had become an irreplaceable part of discussion about public access rights to nature. This 
is achieved by studying the co-occurrence of allemansrätten with other terms in the two moments in time with collocation analysis and topic modelling. As the focus is on public discussion, the minutes of the parliament are used in this section. Moreover, the uses of the Finnish term jokamiehen/oikeus only are followed, as the majority of the parliamentary speech was in Finnish.

When looking at the debates of the 1970s, concordance searches ${ }^{37}$ for the term reveal important concentrations of allemansrätten in 1973, 1974, 1976 and 1978. They help to identify the key legislative debates in which allemansrätten was used and became defined. In the early 1970s, the new Outdoor Recreation Act was discussed and enacted in Parliament. In 1974 and 1976, the debates regarded the expropriation law and, in 1978, the public use of nature was a topical part of the legislative work on the chemical treatment of forest vegetation.

In the 1990s, several concentrations of the use of the term are found with concordance searches. As expected, the clusters in the 1990s are more numerous and regard a broader variety of themes. In the 1970s, 170 concordance hits are found, which consist of over 90 hits about the Outdoor Recreation Act only and of two smaller concentrations of 10 to 20 hits. In the minutes of the 1990s, on the contrary, 401 hits are found, which are divided rather equally in smaller clusters appearing every year. Most annual hits (56) are found in the 1996 minutes. In the 1990s, allemansrätten appeared as part of debates on nature use and the natural environment, such as hunting and fishing laws and natural protection legislation. Allemansrätten was, however, taken into political debate also in relation to questions about Finland's international relations: the EC/EU membership and legislation concerning foreign ownership in Finland. Allemansrätten, therefore, was used in the 1990s more broadly than merely in the context of access rights in the natural environment.

If we move closer to the level of text, this broadening in the uses of the term becomes more visible. For the comparison, I formed two equal-size debate corpora (about 250,000 characters), which were about similar legislative topics. Similarity of the corpora was sought to minimise the effects created by the mere variance in the legislative topics discussed at the two moments in time. The 1970s debates were used as a starting point, and were contrasted with the legislative projects of the 1990s, which regarded environmental protection, fishing and recreational use of nature. ${ }^{38}$ Furthermore, the corpus was cleaned for obtaining more accurate results for the analysis of co-occurrences: first, the words in the two corpora files were lemmatised with the LAS tool presented in 'Digitised Parliamentary Talk of the 20th Century', above. Second, the texts were trimmed by removing other characters than alphabet letters and deleting the names of the MPs and commonly repeated phrases, such as the greetings addressed to the speaker at the beginning of talks.

When looking at the collocates of 'jokamie* (everyman*) (statistically the most commonly appearing terms with ' jokamie ${ }^{* 39}$ ), we find that allemansrätten retains a common core, but has been used to deliver rather diverse messages. The most frequent collocates shared by both corpora include 'right', 'citizen', 
'nature', 'ice / lure fishing' and 'Finland', but also 'Nordic'. When we look at differences in collocation (collocates that are not found in the other corpus), the picture becomes nuanced. There are collocates which related mainly to the differences in law projects discussed (even though similar debates were selected for the comparison), such as 'recreational use' or 'chemical treatment product' in the 1970s.

There seem to be differences in relation to how internal or external the uses of allemansrätten have been. The collocates in the 1970s point to the discovery, stabilisation and internal debate about the concept. The most frequent collocates include, for instance, the terms 'age-old', 'property right' / 'property' and 'landowner', and among the statistically most common one finds 'historical', 'heritage' and 'socialise'. In the 1990s, the horizon seems to be broader, and allemansrätten appears rather as something that is being challenged by or being related to the outside world. In the 1990s, the statistically most common collocates include 'unique, 'outsider', 'trample' and 'spoil', and also terms related to space, such as 'international', 'Europe,' 'European' and 'integration'. Even though the 1990s corpus does not include direct debates about EC membership, the discussions on allemansrätten seem to generate questions related to the opening of the borders. Similar fears about the overuse or the weakening of the access rights to nature due to EC membership were also raised in neighbouring Sweden in the early 1990s.

Finally, the differences in co-occurrences between the two corpora are studied by using topic modelling. Topic modelling is a method where separate topics ('patterns of tightly co-occurring terms') are detected in the text corpora through probability analysis. ${ }^{40}$ Topic modelling has proved to be a powerful tool, especially when organising and classifying a large quantity of text documents. ${ }^{41}$ In this section, we do not examine the different topics that are found in the corpus, but we study in detail the topics in which allemansrätten appears. The topic modelling was carried out using the MALLET tool. ${ }^{42}$ MALLET includes automatic removal of stop words, and after testing several shares of topics, MALLET was run to find 80 topics in both corpora. ${ }^{43}$ Besides building the topics, MALLET produces an output file, where the words in the corpus are annotated by their topic number. The results of 'jokamie $e^{\star}$ (everyman ${ }^{\star}$ ) appearing in different topics is presented in Figure 11.3.

As illustrated very clearly in the graph above, MALLET clustered allemansrätten mainly to two different topics. To a large extent, this results due to the functionalities of the method, as the data had been lemmatised and the written word forms used in the 1970s and 1990s were different: topic 49 includes the term 'jokamies' (everyman), whereas topic 76 includes the term 'jokamiehenoikeus' (allemansrätten), which, as we have seen, had become the common written form in the $1990 \mathrm{~s}$

In addition to this, we can discern again a different discursive environment for the two topics and the uses of allemansrätten in the 1970s and 1990s. Topic 


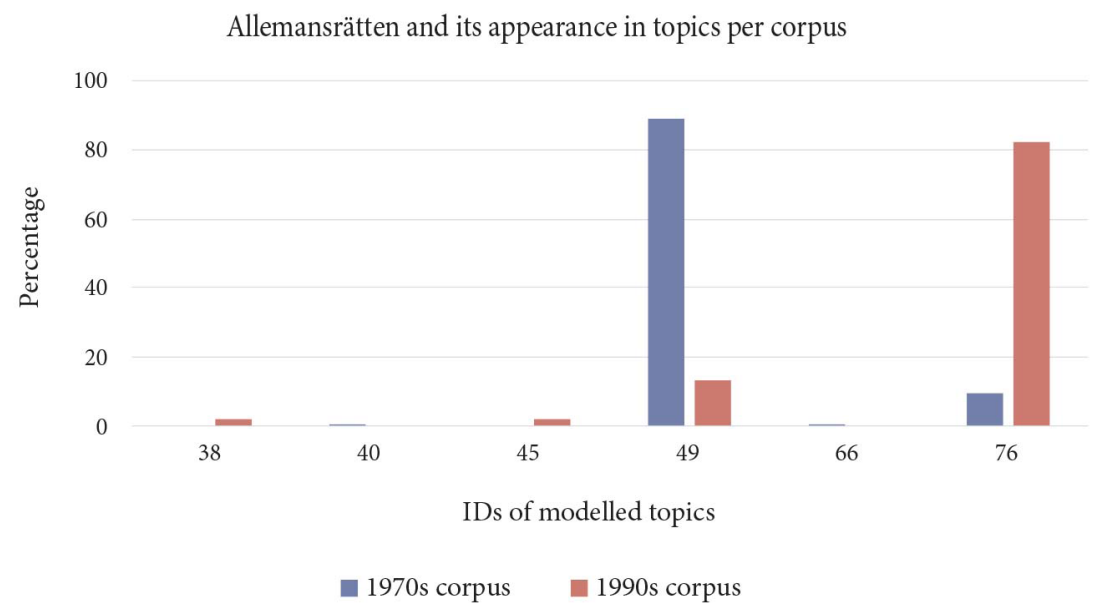

Figure 11.3: Topics in which the term 'jokamie ${ }^{\star}$ (everyman*) was grouped in the topic modelling (per corpus). Source: Author.

49 is mainly about allemansrätten: the main keyword given in topic 49 is 'jokamies' (everyman). This topic includes terms about political debate (political parties) on nature, nature use and access rights. Topic 76, on the other hand, does not have 'jokamiehenoikeus' (allemansrätten) as the main keyword, but the first words of the topic are 'talk', 'damage', 'needs to' and 'pay', and then 'jokamiehenoikeus'. Further down the list of topic terms we find 'damage,' 'problem, 'forest fire', 'Finnish', 'companies' and 'integration'. No names of political groups are listed in topic 49 , and its terms are more related to necessity and change, rather than political negotiation or argumentation.

It seems, then, that allemansrätten expands beyond its 'traditional' range of reference in the period. In the 1970s, allemansrätten appears as part of political debate in which the concept was contested, but the contestation limited itself to the question of access rights to nature. The discussion focused on allemansrätten itself and its roots. Based on a close reading of the corpus, we can highlight as an example the comment put by the agrarian party MP Mikko Kaarna in 1973: 'whatever is meant by this everyman's right, it seems that everybody aims to interpret it in his own way, some of us in a very broad sense. ${ }^{44}$ After this, Kaarna referred to the laws which already regulated outdoor access. In the 1990s, however, allemansrätten conveyed meanings in the political debate that were matters external to access to nature, and rather related to international relations and questions of national identity. For instance, in the debate on the law on natural protection, agrarian party MP Markku Koski emphasised 'how the right, that was very broad for the Finns, should be valued, namely allemansrätten, which does not exist in other European countries to the same extent as in Finland?.5 


\section{Conclusion}

This digital history of allemansrätten in the recently digitised documents of the Finnish Parliament has allowed light to be shed on the trajectory of the Finnish allemansrätten. The methods used in this chapter (keywords search and collocation analysis) have been useful for identifying key debates and studying long-term changes in those debates related to allemansrätten. The chapter has shown how the vocabulary of 'everyman' was already being used extensively before the term allemansrätten came into use. The introduction of fishing rights in the early 1940s presents an important turning point, and depicts key tensions in access rights to nature. Universality in the fishing rights, which is at the core of today's allemansrätten, was criticised with references to the dishonest 'vagabond fishermen' and damages done to the honest locals. ${ }^{46}$ In fact, even though voices were heard for making fishing permanently open for everyone, 'everyman's fishing' was soon limited to allow fishing in the areas where the 'everymen' resided. Importantly, economic reasons, including economic distress, were behind the decision to open the fishing rights. In a similar way, the discussions on wild berry picking in the late 19th century regarded the possibilities for the poor of the rural areas. ${ }^{47}$ Only when strangers outside the local community arrived as 'everymen' to the woods and lakes did it become crucial to define the limits of access rights: the broadening (and creation) of the right was done for economic reasons, not based on a cultural tradition.

The Finnish vocabulary of 'allemansrätten' slowly began to point to universal access rights to nature after the 1950s. In fact, at some point in the 1950s, two conceptual traditions became united. The modern institution of allemansrätten in Finland was modelled after the Swedish example, yet, the Swedish term was not translated into Finnish, but the Finnish expression of 'common man's' and 'normal' access to nature used for wartime fishing rights was taken into use. In the 1970s, then, allemansrätten was an established and commonly used concept in Finland. It appeared in the political debates of the decade, but mainly internally, as something at the centre of attention itself: a 'national heritage' that was discussed and defined by the different national political groups. In the 1990s, the uses of allemansrätten had expanded to various legislative debates. With the normalisation of the concept, allemansrätten could be used externally, to convey meanings related to national values outside the sphere of access rights to nature. In the context of European integration in the early 1990s, it was used to defend a particular Nordic way of life in contrast to European practices of ownership. It is this kind of national symbol, how it is understood (or felt) by the public, which is presented to foreign visitors and used in the branding of the Nordic countries today ${ }^{48}$

In general, the digitised parliamentary data opens up a new research horizon on the public matters of the 20th century. The data complements the digitised national newspapers, which are available comprehensibly for the first three decades of the century only. Yet, the Finnish case presents shortcomings that can 
render digital historical research cumbersome and uninviting: the parliamentary data is not easily accessible through the current web user interface of the Finnish Parliament. ${ }^{49}$ By their nature, parliamentary documents are structured according to time, theme and speaker, and basic search tools and filters that enable the use of these features would satisfy the needs of most historians. ${ }^{50}$ In this chapter, I did not use the web interface, but applied textual analysis methods on the parliamentary data. These methods are applicable by historians with basic computational skills; however, a significant amount of data work is necessary when using such non-structured and partly weak quality data. It seems to me, therefore, that digital historians should pay extra attention to the workload and the trade-off related to the new digital sources: how much can be done 'easily' with the existing resources by the historian, and what data and development work can and should be left for broader cooperative projects? Moreover, this also implies that historians should actively partake in the digitisation processes of the key historical sources and the development of the related user interfaces.

\section{Notes}

1 Sandell 1997; Husa, Nuotio \& Pihlajamäki 2007: 25-26. For everyman's rights in Finland generally, see Matilainen 2019: 34-35.

2 Wiktorsson 1996.

${ }^{3}$ La Mela 2014; La Mela 2016; Sténs \& Sandström 2016.

${ }^{4}$ Pekonen 2014; La Mela 2016.

${ }^{5}$ Quinn et al. 2010; King 2016; Abercrombie \& Batista-Navarro 2018.

${ }^{6}$ La Mela 2016.

7 Ihalainen \& Palonen 2009.

${ }^{8}$ Ihalainen, Ilie \& Palonen 2016. For a list of the available parliamentary corpora by CLARIN, see https://www.clarin.eu/resource-families/parlia mentary-corpora.

9 Apilo 2018.

10 Pekonen 2014.

11 Valtiopäivien 2006.

12 Pekonen 2014: 181-225; Voutilainen 2016.

13 The Documents are the main collection of the parliamentary documents (government proposals and committee statements, for instance), and the Annexes contain the motions of the MPs.

${ }^{14}$ See, e.g., Riksdagshandlingarna 2012.

15 Digitoidut valtiopäiväasiakirjat 1907-2000, http://avoindata.eduskunta.fi /digitoidut/.

${ }^{16}$ For example, the speakers' surnames are spelled in the Minutes with spaced text, which the search engine is unable to interpret. MP Koivisto's speaking turn appears in the text as 'Ed. K o I v I s t o:'.

17 XpdfReader, https://www.xpdfreader.com/about.html. 
18 For example, page numbers were removed and text column recognition errors corrected.

${ }^{19}$ Linguistic Analysis Command-Line Tool, version 1.5.15, https://github .com/jiemakel/las.

${ }^{20}$ Mäkelä 2016.

${ }^{21}$ Kettunen \& Pääkkönen 2016.

${ }^{22}$ Finnish NGO 2018.

${ }^{23}$ Sandell 1997.

${ }^{24}$ Kardell 2004: 234.

${ }^{25}$ La Mela 2016.

${ }^{26}$ The keywords used in the search were jokamie ${ }^{\star}$ and joka mieh*, which capture both written forms of the term allemansrätten in Finnish: jokamiehen oikeus and joka miehen oikeus.

27 La Mela 2014: 271-272; La Mela 2016: 218-219.

${ }^{28}$ Jokamiehen —ja joka naisen —viikkolehti. No. 3 (19 October 1907).

29 'Minä tahtoisin sanoa: puolustuskysymys on meillä joka miehen kysymys. Jokaikisen terveen Suomen miehen on otettava puolustuskysymys omakseen ja omalta osaltaan vastattava siitä.' Minutes of the Parliamentary Session of 1935 (Minutes 1935 II). Helsinki: Valtioneuvoston kirjapaino, 1936, p. 1623.

${ }^{30}$ Brofeldt 1943.

31 ‘... elintarviketilanne ei vielä ole korjautunut sellaiseksi, että voisimme kieltää jokamieskalastajilta mahdollisuuden omalla työllään ansaita itselleen vähäisen särpimen lisän.' Minutes 1945 II, p. 2187.

32 'Minun nähdäkseni kalastusoikeus pitäisi saada vakiinnutetuksi, ei ainoastaan poikkeukseksi, vaan yleiseksi laiksi, että kaikilla kansalaisilla olisi kalastusoikeus.' Minutes 1945 II, p. 2189.

33 'Tosin on vanhastaan katsottu, että maantavan mukaan on olemassa ns. jokamiehen oikeus kulkea toisen maalla ilman omistajan lupaa.' Documents of the Parliamentary Session of 1964 (Documents 1964 V), Question no. 67, p. 2.

${ }^{34}$ Legal scholar V. K. Noponen was already using variants of allemansrätten in Finnish in his work on public and private roads in the 1940 and 1950s. Noponen also refers to concepts developed by the legal scholar S. Ljungman, who was among the first to present this 'newly-found catchphrase with legal value', allemansrätten. La Mela 2016: 216.

${ }^{35}$ Laki yksityisistä teistä. Helsingin Sanomat, no. 264 (30 September 1962), p. 31.

${ }^{36}$ See, e.g., Sandell \& Svenning 2011.

37 The AntConc corpus analysis tool is used for concordance searches and file views. The concordance search was used to detect keywords in the data and study their uses on sentence level. See http://www.laurenceanthony.net /software/antconc/.

38 The selected law projects from the 1990s regard: state outdoor recreation area in Teijo, natural protection act, remuneration of environmental damage and the fishing law. 
39 A range of 10 words before and after the term was used to study collocation.

40 Blei 2012.

${ }^{41}$ See, e.g., Weingart \& Meeks 2012; Wehrheim 2018.

${ }^{42}$ MALLET toolkit, http://mallet.cs.umass.edu/.

${ }^{43}$ A different number of topics were tested manually. The number of topics did not affect the clear distinction between topics presented in Figure 11.3. A larger number of topics was preferred for producing more nuanced topics.

44 'Mitä tällä jokamiehen oikeudella tarkoitettaneenkaan, niin näyttää siltä, että jokainen pyrkii sitä tulkitsemaan omalla tavallaan, monet hyvinkin laajasti.' Minutes 1973 II, p. 1454.

45 'Mielestäni Suomessa nykyisin on pidettävä arvossa sitä oikeutta, mikä suomalaisilla on hyvin laajasti, eli jokamiehenoikeutta, jota ei muissa eurooppalaisissa valtioissa siinä mittakaavassa ole kuin Suomessa.' Minutes 1996 II, p. 1700.

${ }^{46}$ Minister of Agriculture Eemil Luukka on the law proposal on temporary fishing rights: '... jokamieskalastajat tästä lähtien saavat harjoittaa pyyntiään vain vakinaisen tai tilapäisen asuinpaikkansa lähivesistössä. Tämän rajoituksen kautta on tahdottu estää sellainen kulkurikalastajien toiminta, joka juuri on osoittautunut kaikkein haitallisimmaksi paikallisten asukkaiden kalanpyynnille, olkootpa he sitten kalastusoikeutta omaavia tai sitä vailla olevia.' Minutes 1945 II, p. 2187.

${ }^{47}$ La Mela 2016.

${ }^{48}$ Mission for Finland 2010; Tuulentie \& Rantala 2013.

49 Happily, the situation is improving. The research consortium "Semantic Parliament", which aims to produce a linked open data and research infrastructure on Finnish parliamentary data, started its work in January 2020. See https://seco.cs.aalto.fi/projects/semparl/en/.

50 The digitised Canadian parliamentary debates webpage provides a very balanced and user-friendly interface for searching and browsing the parliamentary debates. See http://www.lipad.ca/. See also Beelen et al. 2017.

\section{References}

Abercrombie, G., \& Batista-Navarro, R. (2018, May). 'Aye' or 'no'? Speech-level sentiment analysis of Hansard UK parliamentary debate transcripts. In Proceedings of the Eleventh International Conference on Language Resources and Evaluation (LREC 2018). Miyazaki, Japan (pp. 4173-4180). European Language Resources Association (ELRA). Retrieved from https://www .aclweb.org/anthology/L18-1659.pdf

Apilo, A. (2018, May). Digitized documents in Finnish Parliament. Presentation at Aalto DH Pizza seminar, Otaniemi, Finland.

Beelen, K., Thijm, T. A., Cochrane, C., Halvemaan, K., Hirst, G., Kimmins, M., Lijbrink, S., Marx, M., Naderi, N., Rheault, L., Polyanovsky, R., \& Whyte, T. (2017). Digitization of the Canadian parliamentary debates. 
Canadian Journal of Political Science, 50(3), 849-864. DOI: https://doi .org/10.1017/S0008423916001165

Blei, D. M. (2012). Topic modeling and digital humanities. Journal of Digital Humanities, 2(1).

Brofeldt, P. (1943). Jokamiehen kalastusoikeus ja muut poikkeukselliset kalastusmääräykset. Helsinki: Otava.

Documents of the Parliamentary Session of 1964.

Finnish NGO (2018, 1 October). Finnish NGO nominates 'everyman's right' for UNESCO heritage list. YLE News. Retrieved from https://yle.fi/uutiset /osasto/news/finnish_ngo_nominates_everymans_right_for_unesco _heritage_list/10432231

Husa, J., Nuotio, K., \& Pihlajamäki, H. (Eds.) (2007). Nordic law: between tradition and dynamism. Antwerp: Intersentia.

Ihalainen, P., Ilie, C., \& Palonen, K. (2016). Parliament as a conceptual nexus. In P. Ihalainen, C. Ilie \& K. Palonen (Eds.), Parliament and parliamentarism: a comparative history of a European concept (pp. 1-16). Oxford and New York, NY: Berghahn Books.

Ihalainen, P., \& Palonen, K. (2009). Parliamentary sources in the comparative study of conceptual history: methodological aspects and illustrations of a research proposal. Parliaments, Estates and Representation, 29(1), 17-34.

Kardell, L. (2004). Svenskarna och skogen. Vol. 2: Från baggböleri till naturvård. Jönköping: Skogsstyrelsens förlag.

Kettunen, K., \& Pääkkönen, T. (2016, May). Measuring lexical quality of a historical Finnish newspaper collection-analysis of garbled OCR data with basic language technology tools and means. In Proceedings of the Tenth International Conference on Language Resources and Evaluation (LREC 2016). Portoroz, Slovenia (pp. 956-961). European Language Resources Association (ELRA). Retrieved from http://www.lrec-conf.org/proceedings /1rec2016/pdf/17_Paper.pdf

King, L. (2016). Future citizens: cultural and political conceptions of children in Britain, 1930s-1950s. Twentieth Century British History, 27(3), 389-411. DOI: https://doi.org/10.1093/tcbh/hww025

La Mela, M. (2014). Property rights in conflict: wild berry-picking and the Nordic tradition of allemansrätt. Scandinavian Economic History Review, 62(3), 266-289. DOI: https://doi.org/10.1080/03585522.2013.876928

La Mela, M. (2016). The politics of property in a European periphery: the ownership of books, berries, and patents in the Grand Duchy of Finland 1850-1910 (doctoral dissertation, European University Institute, Florence). DOI: https://doi.org/10.2870/604750

Matilainen, A. (2019). Feelings of psychological ownership towards private forests (doctoral dissertation, University of Helsinki, Faculty of Agriculture and Forestry). Retrieved from http://hdl.handle.net/10138/300433

Minutes of the Parliamentary Sessions of 1935, 1945, 1973, 1996. 
Mission for Finland. (2010). Mission for Finland: Country brand report 25.11.2010. Final report of the Country Brand Delegation. Retrieved from http://www.maakuva.fi/wp-content/uploads/2011/06/TS_Report_EN.pdf

Mäkelä, E. (2016). LAS: an integrated language analysis tool for multiple languages. Journal of Open Source Software, 1(6), 35. DOI: https://doi .org/10.21105/joss.00035

Pekonen, O. (2014). Debating 'the ABCs of parliamentary life': the learning of parliamentary rules and practices in the late nineteenth-century Finnish Diet and the early Eduskunta. Jyväskylä: University of Jyväskylä.

Quinn, K. M., Monroe, B. L., Colaresi, M., Crespin, M. H., \& Radev, D. R. (2010). How to analyze political attention with minimal assumptions and costs. American Journal of Political Science, 54(1), 209-228.

Riksdagshandlingarna. (2012). Riksdagshandlingarna det finländska parlamentstrycket: handledning [A guide to the Finnish parliamentary documents]. Library of the Parliament of Finland. Retrieved from http:// www.eduskunta.fi/SV/tietoaeduskunnasta/kirjasto/aineistot/eduskunta /valtiopaivaasiakirjat-tietopaketti/Documents/Handledning-riksdagshan dlingarna.pdf

Sandell, K. (1997). Naturkontakt och allemansrätt: om friluftslivets naturmöte och friluftslivets tillgänglighet i Sverige 1880-2000. Svensk geografisk årsbok, 73, 31-65.

Sandell, K., \& Svenning, M. (2011). Allemansrätten och dess framtid: utredning om allemansrätten. Stockholm: Naturvårdsverket.

Sténs, A., \& Sandström C. (2014). Allemansrätten in Sweden: a resistant custom. Landscapes, 15(2), 106-118.

Tuulentie, S., \& Rantala O. (2013). Will free entry into the forest remain? In D. K. Müller, L. Lundmark \& H. Raynald (Eds.), New issues in Polar tourism (pp. 177-188). Dordrecht: Springer.

Valtiopäivien. (2016). Valtiopäivien alkamis- ja päättymisajat [The beginning and closing dates of the parliamentary seasons]. Retrieved from http:// www.eduskunta.fi/thwfakta/yht/ohje/valtiopaivat.htm

Voutilainen, E. (2016). Tekstilajitietoista kielenhuoltoa: puheen esittäminen kirjoitettuna eduskunnan täysistuntopöytäkirjoissa. In L. Tiittula \& P. Nuolijärvi (Eds.), Puheen kirjallisen esittämisen alueita, keinoja ja rajoja (pp. 162-191). Helsinki: Suomalaisen Kirjallisuuden Seura.

Wehrheim, L. (2018). Economic history goes digital: topic modeling the Journal of Economic History. Cliometrica. DOI: https://doi.org/10.1007 /s11698-018-0171-7

Weingart, S. B., \& Meeks, E. (2012). The digital humanities contribution to topic modeling. Journal of Digital Humanities, 2(1).

Wiktorsson, G. (1996). Den grundlagsskyddade myten: om allemansrättens lansering i Sverige. Stockholm: City University Press. 